\title{
Comparative assessment of antioxidant activity and biochemical composition of four seaweeds, Rocky Bay of Abu Qir in Alexandria, Egypt
}

\author{
Mostafa Mohamed El-SHEEKH ${ }^{1 *}$ (iD), Rania Abd El Khalek EL-SHENODY ${ }^{1}$, Eman Ahmed BASES ${ }^{1}$, \\ Shimaa Mohammed EL SHAFAY ${ }^{1}$
}

\begin{abstract}
The current study estimated the antioxidant activity and biochemical composition of four seaweeds; Toania atomaria (Phaeophyta), Padina pavonia (Phaeophyta), Jania rubens (Rhodophyta) and Corallina elongate (Rhodophyta). The highest total antioxidant activity was observed with ethanol extract of $T$. atomaria ( $44.6 \pm 1.6 \mathrm{mg}$ ascorbic acid equivalents/g crude extract). Among the four seaweeds, ethanol extract of $T$. atomaria has recorded the highest value in ferric reducing antioxidant power (FRAP) assay $(32.3 \pm 0.0 \mathrm{mg}$ ascorbic acid equivalents/g crude extract). The uppermost level of carbohydrates was $(20.4 \% \pm 0.4$ and $19.5 \% \pm 0.7$ dry wt.) in P. pavonia and T. atomaria. Proteins were maximum ( $10.5 \% \pm 0.6$ and $8.0 \% \pm 0.0$ dry wt.) in P. pavonia and T. atomaria. The results detected that $T$. atomaria had the largest amounts of lipids $(5.92 \% \pm 0.09$ dry wt.). The polyunsaturated $\omega 6$ essential fatty acids were recorded in T.atomaria, P. pavonia, and J. rubens (11.39\%, 8.09\%, and 6.28\%), and $\omega 3$ essential fatty acids were recorded in T. atomaria and P. pavonia $(0.65 \%$ and $0.97 \%)$. The seaweeds are interesting candidates for medicinal, pharmaceutical, and nutritional applications owing to their antioxidant activities, biochemical composition; they are not widespread in the coastal waters of Egypt and has few studies, especially T. atomaria.
\end{abstract}

Keywords: marine macroalgae, carbohydrate, lipid, protein, $\omega 3$ and $\omega 6$ essential fatty acids, total antioxidant capacity, ferricreducing antioxidant power.

Practical Application: The search for new natural resources has proven to be healthy, economical, and environmentally friendly, like seaweeds applied as food, antioxidants, and biofuel producers.

\section{Introduction}

In living organisms, reactive oxygen species (ROS) are produced during the metabolic processes and caused oxidative stress impact (Santos-Sánchez et al., 2019). Various chronic diseases, such as atherosclerosis, cancer, and aging may be due to the oxidative damage of the reactive oxygen species on biomolecules (nucleic acids, proteins, and lipids) (Pirian et al., 2017). Antioxidants may mitigate the negative effects of oxidative stress (Larson, 1995; Adwas et al., 2019). Butylated hydroxyl anisole (BHA) and Butylated hydroxyl toluene (BHT), which are synthetic antioxidants, were showed to be poisonous and carcinogenic in animal models, so need to be replaced with natural antioxidants (Safer \& Al-Nughamish, 1999; J Mbah et al., 2019). Furthermore, novel resources of safe and cheap antioxidants of the natural source should be identified.

Seaweeds are marine, photosynthetic algae that are abundant in every ocean. There are three main phyla of seaweed: Chlorophyta (green algae), Rhodophyta (red algae), and Phaeophyta (brown algae) (Shannon \& Abu-Ghannam, 2019). Strong antioxidant properties have shown with seaweed extracts (Ibrahim et al., 2016; Mohy El-Din \& El-Ahwany, 2016; Ismail et al., 2019; El-Shenody et al., 2019; Al-Araby et al., 2020). Barba (2017) and Lopez-Santamarina et al. (2020) reported that marine macroalgae contain an excellent source of bioactive components like dietary fibers, carotenoids, essential fatty acids, protein, minerals, and vitamins. In many Asian countries such as China, Japan, and Korea, seaweeds have been used as a food resource (Wijesekara et al. 2012).

The most remarkable biochemical compounds of algae are carbohydrates, proteins, and lipids. Khairy \& El-Shafay, (2013) mentioned that lipids are commonly found in many algal resistance stages. Studies on the fatty acids of seaweeds and microalgae were few (Lie Ken Jie, 1989; Khairy \& El-Shafay, 2013). The biomass of seaweeds can store high contents of oil, which can be consumed for biodiesel production (John \& Anisha, 2012; Peng et al., 2020). For several coastal areas of the world, a few populations of Padina have usually been used as a food supply, generally recognized as gelatin-like sweetmeat (Robledo \& Freile Pelegrín, 1997).

In the present study, T. atomaria is an annual photophilic species of the infralittoral zone, found in calm areas, with a greater occurrence in the early summer and very few individuals from late summer to late winter (Sala \& Boudouresque, 1997). Coralline algae (Rhodophyta) play a vital role in fostering dominion of other benthic organisms, becoming the source of food source for herbivores, involving in the stabilization of reef networks, and in the production of carbonate. One of the most popular 
coralline species, Jania rubens, that may survive as epiphytic or epilithic tufts in shallow environments (Porzio et al., 2018).

The purpose of this study is to search the biochemical content and fatty acid profile of four different seaweeds T. atomaria, P. pavonia, J. rubens, and C. elongate, which are commonly found in Rocky Bay of Abu Qir in Alexandria, Egypt. The pharmaceutical, medicinal, and nutritional applications of the studied seaweeds were confirmed by estimating the antioxidant activities of these seaweed extracts.

\section{Materials and methods}

\subsection{Seaweeds collection}

Jania rubens, Coralina elongate, Padina pavonia, and Toania atomaria were collected freshly from Rocky Bay of Abu Qir in Alexandria, Egypt (Figure 1). Collected samples were washed carefully with marine water then tap water, transferred in an iced condition to the Phycology laboratory. The collected samples were air-dried in the shade at room temperature then in the oven at $38 \pm 2{ }^{\circ} \mathrm{C}$; the dried seaweeds were ground to a fine powder and stored for further studies in tightly closed containers. For taxonomical identification, a portion of the collected samples were stored in 3-4\% formalin in seawater or distilled water. The seaweeds were identified according to (Aleem 1993; Jha et al. 2009; Kanaan \& Belous 2016), then using the Algae Base website to confirm their identification and the habitat details (Guiry \& Guiry, 2019).

\subsection{Preparation of the algal extracts (Conventional method)}

The extraction was performed with several solvents (methanol, ethanol, hexane, diethyl ether, aqueous cold, aqueous hot) by steeping the material in the corresponding solvents $(1: 30 \mathrm{w} / \mathrm{v})$ within a conical flask then closed with cotton wool. Next, retained on a rotatory shaker at $120 \mathrm{rpm}$ at $20-30{ }^{\circ} \mathrm{C}$ for 2 days. The extracts were filtered, and the filtrate put in the oven at $45^{\circ} \mathrm{C}$ to get rid of the solvent. The crude extracts were suspended in the corresponding solvents to obtain a final concentration of $5 \mathrm{mg} / \mathrm{mL}$ then kept at $-20^{\circ} \mathrm{C}$ in an airtight container to control the microbial contamination.

For the hot water extraction, soaking $1 \mathrm{~g}$ of seaweed powder in $30 \mathrm{~mL}$ distilled water for 2 hours at $60^{\circ} \mathrm{C}$ then repeated the previous steps for extract preparation as mentioned above.

The extraction yield percentage of each extract was calculated according to (Maisuthisakul \& Pongsawatmanit, 2004): Extraction yield $\%=(\mathrm{W} 1 / \mathrm{W} 2)^{\star} 100$.

Where W1 is the dried crude extract weight, and W2 is the sample weight before extraction (1 gm).

\subsection{Antioxidant activities estimation}

\section{Total Antioxidant Capacity (TAC) assay}

The total antioxidant capacity (TAC) was determined, as reported by (Sun et al., 2011). In brief, $0.3 \mathrm{~mL}$ of the crude extracts was added to $3 \mathrm{~mL}$ of reagent solution ( $4 \mathrm{mM}$ ammonium molybdate, $28 \mathrm{mM}$ sodium phosphate, and $0.6 \mathrm{M}$ sulfuric acid). Absorbance was measured at $695 \mathrm{~nm}$ against a blank). Total antioxidant capacity was expressed (mg ascorbic acid equivalents/g crude extract).

\section{Ferric-reducing antioxidant power (FRAP) assay:}

Ferric- reducing antioxidant power (FRAP) was estimated by the method reported by (Zubia et al., 2007). Aliquots $(0.5 \mathrm{~mL})$ of the extracts were added to $1.25 \mathrm{~mL}$ of sodium phosphate buffer (0.2 M, pH 6.6), $1.25 \mathrm{~mL}$ of (1\%) potassium ferricyanide $\left(\mathrm{K}_{3} \mathrm{Fe}(\mathrm{CN})_{6}\right)$. Afterward, the mix was kept at $50{ }^{\circ} \mathrm{C}$ for $20 \mathrm{~min}$ in a water bath. The mixture was cooled and mixed with $1.25 \mathrm{~mL}$ of $(10 \%)$ trichloroacetic acid, and then $1.25 \mathrm{~mL}$ of the mixture was added to $1.25 \mathrm{~mL}$ distilled water, $0.25 \mathrm{~mL}$ of $(0.1 \%)$ ferric chloride solution $\left(\mathrm{FeCl}_{3} \cdot 6 \mathrm{H}_{2} \mathrm{O}\right)$. Absorbance was

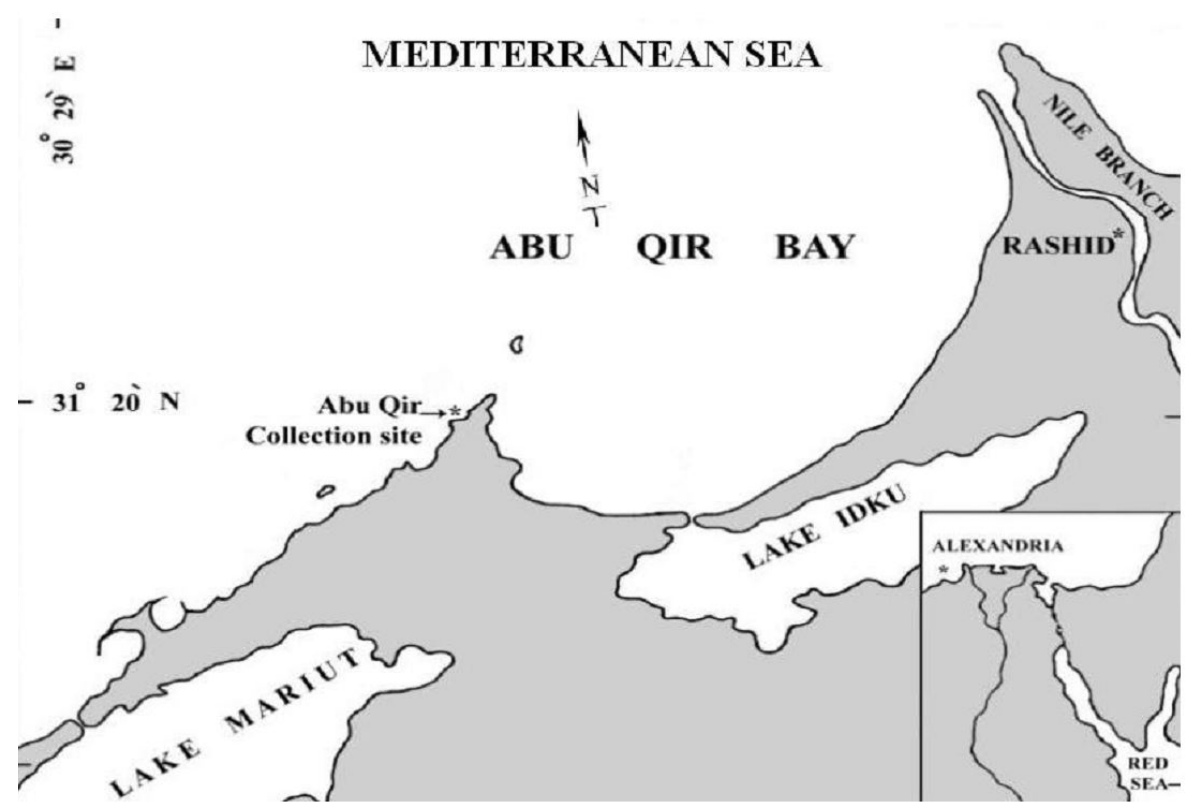

Figure 1. Map of Abu Qir showing collection site (Abu Qir bay located in Abu Qir, Alexandria). 
measured against blank. Higher absorbance marked increased reducing power. Ferric- reducing antioxidant power (FRAP) was reported as mg ascorbic acid equivalents/g crude extract.

\subsection{Chemical composition of Seaweeds}

Estimation of total soluble carbohydrates and total soluble protein

The sample ( 0.1 g powder) was extracted with $\mathrm{NaOH}(1 \mathrm{~N})$ in a water bath at $100^{\circ} \mathrm{C}$ for 2 hours, cooled the extract, and centrifugation done as represented by (Payne \& Stewart, 1988).

\section{- A- Total content of soluble carbohydrates}

Total soluble carbohydrate was quantitatively estimated by the method of Phenol-Sulphoric acid described by (Kochert, 1973). The absorbance was determined at $490 \mathrm{~nm}$ against a blank. The carbohydrate concentration was stated after the creation of a calibration curve using glucose as a standard. Total carbohydrate content was given as a percentage of the algal dry weight $\% \mathrm{DW}$.

\section{- B-Total content of soluble protein}

Total soluble protein was assessed using the method of Bradford (1976). The absorbance was measured at $595 \mathrm{~nm}$ against a blank. Bovine Serum Albumin was used as a standard to evaluate the calibration curve. Total protein content was given as a percentage of the algal dry weight $\% \mathrm{DW}$.

\section{Estimation of lipids}

Total lipid content

Lipid was determined as reported by the modified Folch method (Folch et al., 1957) with some modifications.

\section{Composition of fatty acids}

\section{- A- Preparation of methyl ester of fatty acids}

The transmethylation of lipids and extraction of fatty acid methyl esters (FAMEs) were prepared from aliquots comprising total lipids, as mentioned by (Radwan, 1978), stored at $4{ }^{\circ} \mathrm{C}$ in the dark before GC-MS analysis.

- B- Gas liquid chromatography of methyl esters of fatty acids.
GC-MS spectrophotometry (Perkin Elmer model: Clarus 580/560 S) was used for the analysis of the fatty acid methyl esters (FAMEs). Acquisition parameters were oven initial temperature $60^{\circ} \mathrm{C}$ for $2 \mathrm{~min}$ which ramped from $10^{\circ} \mathrm{C} / \mathrm{min}$ to $280^{\circ} \mathrm{C}$, hold $6 \mathrm{~min}$, Injector temperature $=250^{\circ} \mathrm{C}$, Source temp $=200^{\circ} \mathrm{C}$, Transfer temp $=250^{\circ} \mathrm{C}$, Column (Rxi-5Sil MS column $30 \mathrm{~m}$, $0.25 \mathrm{~mm} \mathrm{ID}, 0.25 \mathrm{df})$, Scan $=50$ to $500 \mathrm{Da}$, Split ratio $=20: 1$, Injectionvolume $=1.0 \mu \mathrm{L}$ of fatty acid methyl esters, Carrier gas $=$ Helium, Solvent delay $=5.00 \mathrm{~min}$.

\subsection{Statistical analysis}

All the assays were performed in triplicate, and the means \pm standard deviation (SD) were recorded. The seaweed extraction yield and antioxidant activities were compared by custom tables using the SPSS 23.0 software, significant values at $p<0.05$. The statistically significant difference between the chemical composition of seaweed was identified by the analysis of variance (One-way ANOVA) followed by Duncan's multiple range test for data with significant differences, at $p<0.05$, using the SPSS 23.0 software.

\section{Results and discussion}

The extraction efficiency is strongly influenced by the extraction method, extraction time, the solvent used, temperature, and the phytochemicals composition (Turkmen et al., 2006; van Ngo et al., 2017). According to the findings of this study, the solvent is identified as one of the most important parameters under the same extraction conditions. The current study used distilled water (cold and hot) and organic solvents (methanol, ethanol, diethyl ether, and hexane) to extract bioactive compounds from collected seaweeds.

\subsection{Taxonomic description of collected seaweeds}

The collected species were identified as presented in the literatures, checked for synonyms and latest accepted names, referred to its systematic groups, and described. The collected species were Padina pavonica (Linnaeus) Thivy or Padina pavonia (Linnaeus) J.V.Lamouroux and Taonia atomaria (Woodward) J. Agardh from Phaeophyceae, Jania rubens (Linnaeus) J.V.Lamouroux, Corallina elongate Ellis et Solander from Rhodophyceae (Figure 2A, B, C and D).
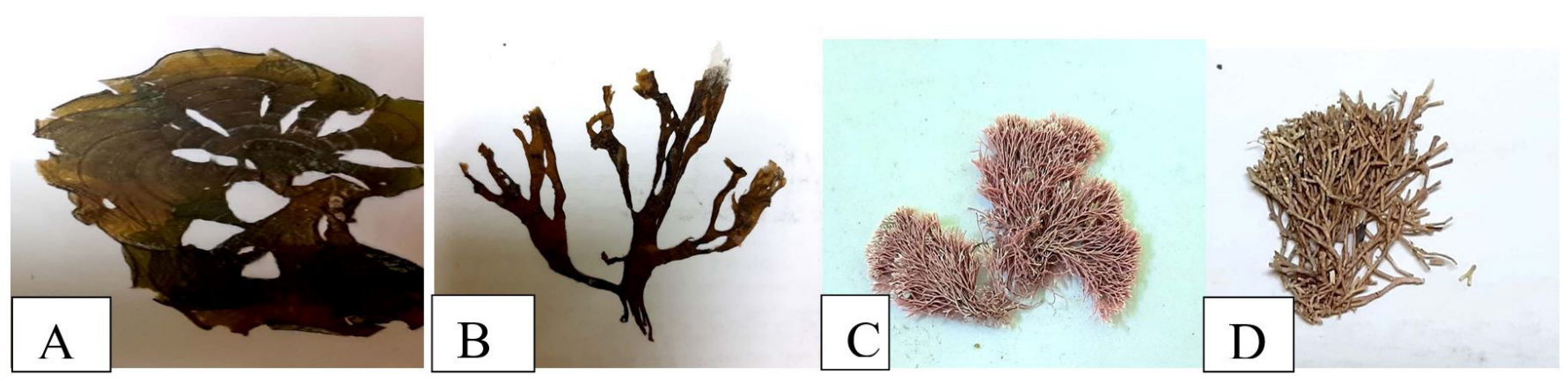

Figure 2. Photos of the studied seaweeds (A) Padina pavonia (B) Taonia atomaria (C) Jania rubens (D) Corallina elongate. 


\subsection{Extraction yield}

Different solvents with various polarities were used for extraction. Also, the obtained crude extracts were used to evaluate the antioxidant activities using different methods due to the presence of different bioactive components with antioxidant potential. Moreover, the polarity index of extraction solvents was: methanol (5.1), ethanol (5.2), water (9.0), diethyl ether (2.8), and hexane (0.1). Table 1 indicates that the extraction yield increased with increasing solvent polarity. The trend indicated relatively greater yields of polar solvents vis a vis non-polar solvents in red and brown algae, while the brown alga remains the highest yielding. This result is consistent with (Truong et al., 2019), who observed that the extraction efficiency favors the highly polar solvents in Severinia buxifolia. This may be due to the plant material has great levels of polar compounds which are soluble in solvents with a high polarity such as water, methanol, and ethanol. In order to better understand the solvents effect on extraction yield, further analysis was performed to measure the antioxidant potential of bioactive compounds in the extract. These large variations in extraction yield detected among different seaweed species may be due to the fact that the polarities of different components present in the seaweeds and also species-species differences (Agregán et al., 2017, 2018).

Extraction yield of four seaweeds collected extracted with different solvents (aqueous cold, aqueous hot, methanol, ethanol, diethyl ether, and hexane) are recorded in (Table 1). With regard to the effect of different extraction solvents on the yield of the studied seaweeds, T.atomaria $(16.5 \% \pm 0.2)$ recorded the highest yield value with methanol extract; however, J. rubens $(0.2 \% \pm 0.0)$ showed the lowest yield value in hexane extract. The yield of methanolic extract in the current study was larger as compared to the earlier study by (Chakraborty et al., 2015), who recorded a $5.32 \mathrm{~g} / 100 \mathrm{~g}$ dry sample of total methanol extract in J. rubens (red seaweed). In the present study, the methanol extract yield was higher than the values previously reported, including Padina pavonica (6.5\%), Colpomenia sinuosa (4.7\%), Cystoseira myrica (4.3\%) and Ulva lactuca (3.3\%) (Kokabi et al., 2013). Furthermore, the yield of the extracts varies, ranging from 1.5 to $4.1 \%$ in other types of seaweeds, such as red seaweeds (Ganesan et al., 2008).

\subsection{Evaluation of antioxidant activities}

Antioxidants turn reactive oxygen species to non-toxic compounds, inhibit the adverse effects of reactive oxygen species and reduce some disorders, such as infections and ischemia, diabetes infections, cardiovascular and cancer diseases (Rady et al., 1994; Al-Dabbas, 2017). Hence, in this study, the evaluation of antioxidant activities of the collected seaweeds extracted with different solvents carried out by two methods:

\section{Total Antioxidant Capacity (TAC) assay.}

2. Ferric reducing antioxidant power (FRAP) assay.

\section{Total Antioxidant Capacity (TAC) assay}

The attention of researchers was focused on the ability of algae to accumulate antioxidant compounds, as the environment in which seaweeds grow is harsh and can cause the formation of strong oxidizing agents; however, seaweeds rarely know any severe photodynamic damage during metabolism. Such a fact means that the cells of seaweed have developed a complex protective system to bear salinity (Zubia et al., 2007). The quantitative total antioxidant capacity (TAC) of the algal extract was assessed by a phosphomolybdenum assay. The TAC of the extracts or standards was measured depend on the reduction of molybdenum (Abifarin et al., 2019). Biologically, antioxidants perform their health-useful roles by transferring an electron or hydrogen $(\mathrm{H})$ atom to reactive species, so inhibit them (Apak et al., 2016). Thus, measurements of the antioxidant potential may generally be through hydrogen atom transfer (HAT) and single electron transfer dependant assays (SET). SET assays determine the potential of an antioxidant to reduce an oxidant, which alters colour when reduced. SET assays such as Total Antioxidant Capacity (TAC) and Ferric reducing antioxidant power (FRAP) assays were able to measure the reduced capacity. Pérez-Jiménez \& Saura-Calixto, (2006) stated that the type and polarity of solvent might affect the hydrogen atom transfer and the single electron transfer, which are major aspects in the estimation of antioxidant capacity. However, the total antioxidant activity of 245-376 mg ascorbic acid/g crude extract has been detected in extracts of a higher plant (Kumaran \& Karunakaran, 2007). Published studies on the total antioxidant activity of seaweed extracts are not available. As well, it has been mentioned that solvents used for extraction have a significant effect on the chemical species (Yuan et al., 2005).

The total antioxidant activity of the four seaweeds extracted with different solvents was recorded in Table 2. The present results showed that methanol, ethanol, diethyl ether, hexane, aqueous cold, and hot aqueous extracts of four seaweeds (Rhodophyta and Phaeophyta) possessed antioxidant activities. The methanol

Table 1. Yield value of four seaweeds collected from Rocky Bay of Abu Qir in Alexandria, Egypt extracted with different solvents (as \% w/w of seaweed on dry weight basis).

\begin{tabular}{|c|c|c|c|c|c|c|}
\hline \multirow{3}{*}{ Seaweeds } & \multicolumn{6}{|c|}{ Solvents } \\
\hline & Methanol & Ethanol & Aqueous hot & Aqueous cold & Diethylether & Hexane \\
\hline & \multicolumn{6}{|c|}{ Yield (\%) } \\
\hline P. pavonia & $7.9 \pm 0.8^{\mathrm{Aa}}$ & $15.6 \pm 0.2^{\mathrm{Ba}}$ & $5.5 \pm 0.3^{\mathrm{Ca}}$ & $6.9 \pm 0.7^{\mathrm{Aa}}$ & $1.1 \pm 0.0^{\mathrm{Da}}$ & $0.3 \pm 0.0^{\mathrm{Da}}$ \\
\hline J. rubens & $2.7 \pm 0.0^{\mathrm{Ab}}$ & $2.0 \pm 0.1^{\mathrm{Bb}}$ & $1.4 \pm 0.1^{\mathrm{Cb}}$ & $5.0 \pm 0.2^{\mathrm{Db}}$ & $0.5 \pm 0.0^{\mathrm{Eb}}$ & $0.2 \pm 0.0^{\mathrm{Fa}}$ \\
\hline T.atomaria & $16.5 \pm 0.2^{\mathrm{Ac}}$ & $10.5 \pm 0.1^{\mathrm{Bc}}$ & $12.3 \pm 0.2^{\mathrm{Cc}}$ & $13.5 \pm 0.1^{\mathrm{Dc}}$ & $4.8 \pm 0.1^{\mathrm{Ec}}$ & $4.3 \pm 0.0^{\mathrm{Fb}}$ \\
\hline C.elongate & $2.1 \pm 0.2^{\mathrm{Ab}}$ & $1.8 \pm 0.2^{\mathrm{Ab}}$ & $4.6 \pm 0.1^{\mathrm{Bd}}$ & $4.4 \pm 0.2^{\mathrm{Bb}}$ & $0.8 \pm 0.2^{\mathrm{Cb}}$ & $1.6 \pm 0.2^{\mathrm{Ac}}$ \\
\hline
\end{tabular}

Values are the mean of three replicates \pm SD; Values with the same capital letter in the same row showed insignificant differences (at $\mathrm{P}<0.05$ ); Values with the small letter in the same column showed insignificant differences (at $\mathrm{P}<0.05$ ). 
extract showed the highest antioxidant activities for all tested seaweeds except T. atomaria. T. atomaria observed the highest antioxidant activity in ethanol extract (44.6 $\pm 1.6 \mathrm{mg}$ ascorbic acid equivalents/g crude extract), and it recorded the highest value between different solvents and seaweeds this action may be due to Lipids (soluble Lipids, PUFAs, and steroids) (El Baz et al., 2014), sterol fraction (Ibrahim et al., 2016), taondiol and epitaondiol metabolites (Nahas et al., 2007) which had high antioxidant activity. Hexane extract showed the lowest antioxidant activities for all tested seaweeds except $P$. pavonia, which had the lowest antioxidant activity with diethyl ether extract ( $0.5 \pm 0.1 \mathrm{mg}$ ascorbic acid equivalents/g crude extract). J. rubens showed the lowest antioxidant activity in hexane extract with $0.14 \pm 0.0 \mathrm{mg}$ ascorbic acid equivalents/g crude extract. Data presented in Table 2 indicated variations in TAC, which may be attributed to species differences. Accordingly, all the studied species are considered a rich source of antioxidants. Indu \& Seenivasan (2013) reported that brown seaweeds possessed good antioxidant activity when compared to red and green seaweeds, and this explains that brown algae T. atomaria and P. pavonia exhibited the highest TAC. In J. rubens, methanol and ethanol extract give nearly equal results in TAC. In general, methanol was the most effective solvent for the extraction of antioxidant compounds from seaweeds, which may be because methanol having a larger dielectric constant than ethanol. We found that methanol extracts of J. rubens, P. pavonia, and C. elongate more reactive than the other extracts. Similar results were previously obtained by (Mohy El-Din \& El-Ahwany, 2016), who stated that methanol extract of Corallina mediterranea was found to have the highest total antioxidant capacity. Other reports informed that methanol, etahanol, acetone and water extract of Padina pavonica (Ismail et al., 2019), sterol fraction of Toania atomaria (Ibrahim et al., 2016), methanol, ethanol, acetone and chloroform extract of Jania rubens (Mohy El-Din
\& El-Ahwany, 2016) and chloroform extract of Jania rubens (Saeed et al., 2020) had a significant antioxidant activity in Total Antioxidant Capacity assay. It is still unobvious what type of solvent is the most efficient and favorable for seaweeds extraction. Although different solvents have been used in screening algae for antioxidants (Yi et al., 2001; Manch et al., 2014). The antioxidant activity might be attributable to the presence of PUFAs and lipophilic antioxidants such as phenolic and terpenoid compounds, total carotenoids, and a-tocopherol (El Baz et al., 2014).

\section{Ferric reducing antioxidant power (FRAP) assay}

Ferric reducing antioxidant power (FRAP) in the crude extracts of the four collected algae were recorded in Table 3. In FRAP, The ability of the antioxidant compounds in the extract to reduce ferric (III) to ferrous (II) in a redox-linked colorimetric reaction that includes single electron transfer determined the antioxidant activity (Li et al., 2006; Sumayya \& Murugan, 2019). With regard to different solvents, ethanol extract of T. atomaria recorded the highest ferric reducing antioxidant power (FRAP) (32.3 $\pm 0.0 \mathrm{mg}$ ascorbic acid equivalents/g crude extract), and these values were the highest between solvents and seaweeds. Hexane and diethyl ether extracts showed the lowest ferric, reducing antioxidant power (FRAP) for all tested seaweeds. Duh (1998) stated that reducing properties are generally related to the presence of reductions. Reductions also prevent peroxide formation as they react with certain precursors of peroxide. The results indicate that the remarkable antioxidant activity of the tested seaweeds extracts was due to their reducing power. The components from these seaweeds may work as reductions by donating electrons and reacting with free-radicals to convert them to more stable products and ending the free-radical chain reaction.

Table 2. Total antioxidant activity (mg ascorbic acid equivalents/g crude extract) of four seaweeds extracted with different solvents (concentration of extracts used $=5 \mathrm{mg} / \mathrm{mL}$ ).

\begin{tabular}{|c|c|c|c|c|c|c|}
\hline \multirow{3}{*}{ Seaweeds } & \multicolumn{6}{|c|}{ Solvents } \\
\hline & Methanol & Ethanol & Aqueous hot & Aqueous cold & Diethyl ether & Hexane \\
\hline & \multicolumn{6}{|c|}{ TAC (mg ascorbic acid equivalents/g crude extract) } \\
\hline P. pavonia & $30.8 \pm 2.1^{\mathrm{Aa}}$ & $19.8 \pm 0.4^{\mathrm{Ba}}$ & $15.3 \pm 0.4^{\mathrm{Ca}}$ & $5.1 \pm 0.1^{\mathrm{Da}}$ & $0.5 \pm 0.1^{\mathrm{Ea}}$ & $2.6 \pm 0.2^{\mathrm{Ea}}$ \\
\hline T. atomaria & $37.6 \pm 2.0^{\mathrm{Ab}}$ & $44.6 \pm 1.6^{\mathrm{Bc}}$ & $14.6 \pm 0.2^{\mathrm{Ca}}$ & $19.9 \pm 0.2 .7^{\mathrm{Db}}$ & $7.6 \pm 0.0^{\mathrm{Eb}}$ & $5.7 \pm 0.2^{\mathrm{Ec}}$ \\
\hline C. elongate & $25.1 \pm 0.3^{\mathrm{Ac}}$ & $17.3 \pm 1.0^{\mathrm{Ba}}$ & $17.3 \pm 0.1^{\mathrm{Bc}}$ & $4.0 \pm 0.1^{\mathrm{Ca}}$ & $2.6 \pm 0.0^{\mathrm{Dc}}$ & $0.38 \pm 0.1^{\mathrm{Eb}}$ \\
\hline
\end{tabular}

Values are the mean of three replicates \pm SD; Values with the same capital letter in the same row showed insignificant differences (at $\mathrm{P}<0.05$ ); Values with the small letter in the same column showed insignificant differences (at $\mathrm{P}<0.05)$. TAC $=$ total antioxidant capacity.

Table 3. Ferric reducing antioxidant power (FRAP) assay (mg ascorbic acid equivalents/g crude extract) of four seaweeds extracted with different solvents (concentration of extracts used $=5 \mathrm{mg} / \mathrm{mL}$ ).

\begin{tabular}{|c|c|c|c|c|c|c|}
\hline \multirow{2}{*}{ Seaweeds } & Methanol & Ethanol & Aqueous hot & Aqueous cold & Diethylether & Hexane \\
\hline & \multicolumn{6}{|c|}{ FRAP(mg ascorbic acid equivalents/g extract) } \\
\hline P. pavonia & $13.6 \pm 0.2^{\mathrm{Aa}}$ & $11.2 \pm 0.3^{\mathrm{Ba}}$ & $6.7 \pm 0.2^{\mathrm{Ca}}$ & $4.3 \pm 0.1^{\mathrm{Da}}$ & $0.4 \pm 0.1^{\mathrm{Ea}}$ & $0.8 \pm 0.2^{\mathrm{Ea}}$ \\
\hline J. rubens & $22.7 \pm 1.0^{\mathrm{Ab}}$ & $22.4 \pm 1.7^{\mathrm{Ab}}$ & $15.4 \pm 0.4^{\mathrm{Bb}}$ & $18.5 \pm 1.4^{\mathrm{Cb}}$ & $0.7 \pm 0.0^{\mathrm{Db}}$ & $0.35 \pm 0.0^{\mathrm{Db}}$ \\
\hline T. atomaria & $22.6 \pm 0.8^{\mathrm{Ab}}$ & $32.3 \pm 0.0^{\mathrm{Bc}}$ & $21.7 \pm 0.0^{\mathrm{Ac}}$ & $21.8 \pm 0.1^{\mathrm{Ac}}$ & $2.5 \pm 0.2^{\mathrm{Cc}}$ & $4.1 \pm 0.2^{\mathrm{Dc}}$ \\
\hline C. elongate & $4.1 \pm 0.1^{\mathrm{Ac}}$ & $3.3 \pm 0.2^{\mathrm{Bd}}$ & $3.5 \pm 0.0^{\mathrm{Bd}}$ & $0.1 \pm 0.0^{\mathrm{Cd}}$ & $0.1 \pm 0.0^{\mathrm{Cd}}$ & $0.25 \pm 0.0^{\mathrm{Cb}}$ \\
\hline
\end{tabular}

Values are the mean of three replicates \pm SD; Values with the same capital letter in the same row showed insignificant differences (at $\mathrm{P}<0.05$ ); Values with the small letter in the same column showed insignificant differences (at $\mathrm{P}<0.05$ ). 
The present data are in accordance with (Kelman et al., 2012; Ismail et al., 2017), who reported that the antioxidant activity of brown algae was higher than red groups. Ismail et al. (2017) found that FRAP values of 31.098 and $25.858 \mathrm{mg}$ ascorbic acid equivalents/g extract for Sargassum wightii and Jania rubens, respectively showed the greatest reducing power activity and this findings appeared in line with our results, showed that methanol extract of $J$. rubens recorded higher reducing power than $P$. pavonia.

\subsection{Estimation of primary metabolites (Carbohydrate, protein, and lipid)}

Algae have been one of the most versatile sources of bioactive compounds, and investigation on their chemical composition has significantly extended in the past three decades (Cardozo et al., 2006; O'Sullivan et al., 2010). In general, the nutritional values of seaweeds are defined according to biochemical composition like carbohydrates, proteins, lipids, and ash content (McDermid \& Stuercke, 2003). Carbohydrates, protein, and lipids are the most important biochemical components in algal biomass. Significant differences ( $p \leq 0.05)$ were recorded in carbohydrate, protein, and lipid contents (Table 4). Yoshii et al. (2004) stated that the ratios of each constituent change between the species based on the taxon. The results showed that the carbohydrate contents were more numerous than the protein and lipid contents.

The total soluble carbohydrate contents of the studied seaweeds ranged from $6.4 \%$ to $20.4 \%$. P. pavonia $(20.4 \% \pm 0.4)$ and $T$. atomaria $(19.5 \% \pm 0.7)$ was recorded the highest value in carbohydrate contents, while the lowest value showed with C. elongate $(6.7 \% \pm 0.5)$ and $J$. rubens $(6.4 \% \pm 0.4)$. Similar values were found in the brown alga Sargassum horneri (19.93\% DW) (Hossain et al., 2003). These variations may be due to the species difference, growth stage of each species, habitat, metabolic preferences, and photosynthetic activity (Pádua et al., 2004). The brown algae were rich in carbohydrate content than red algae, and these findings are in agreement with (El-Shenody et al., 2019). Carbohydrate usually contains excellent amounts of polysaccharides, for example, carrageenan in the red seaweeds, alginate, and fucoidan in the brown seaweeds, so this high content of carbohydrate is essential for the metabolism of the organism. Venkatesan et al. (2017) and Barbosa et al., (2019) demonstrated that promising biomedical applications, including antibacterial, antiviral, anticoagulant, anti-inflammatory, and

Table 4. Total soluble carbohydrate, total soluble protein, and lipid content in the four studied seaweeds.

\begin{tabular}{cccc}
\hline \multicolumn{4}{c}{ Primary metabolites (\%DW) } \\
\hline Seaweeds & Carbohydrate & Protein & Lipid \\
\hline P. pavonia & $20.4 \pm 0.4^{\mathrm{a}}$ & $10.5 \pm 0.6^{\mathrm{a}}$ & $1.28 \pm 0.01^{\mathrm{c}}$ \\
J. rubens & $6.4 \pm 0.4^{\mathrm{c}}$ & $5.1 \pm 0.3^{\mathrm{d}}$ & $1.42 \pm 0.0^{\mathrm{b}}$ \\
T. atomaria & $19.5 \pm 0.7^{\mathrm{b}}$ & $8.8 \pm 0.3^{\mathrm{b}}$ & $5.92 \pm 0.09^{\mathrm{a}}$ \\
C. elongate & $6.7 \pm 0.5^{\mathrm{c}}$ & $8.0 \pm 0.0^{\mathrm{c}}$ & $0.33 \pm 0.06^{\mathrm{d}}$ \\
F-value & 851.54 & 119.08 & 6699.82 \\
p-value & 0.0001 & 0.0001 & 0.0001 \\
\hline
\end{tabular}

Data are expressed as the mean \pm standard deviation (SD) of three replicates. Different letters represent the statistical comparisons between groups by using one-way ANOVA and post hoc Duncan's test $(\mathrm{p}<0.05)$. DW $=$ Dry Weight. anticancer properties, the use as drug coatings in drug delivery systems and antioxidant activities were showed by polysaccharides. The fermentation of macroalgal carbohydrates can be consumed for the production of bioethanol (John \& Anisha, 2012; Sudhakar et al., 2018; Offei et al., 2019).

Similar to the results obtained in the present study (Table 4). Fleurence et al. (2012) showed that the seaweeds protein content is comparatively low, among $3 \%$ to $15 \%$ on the dry weight basis. The results explained here recorded the highest content of protein in the brown seaweeds (P. pavonia and T. atomaria), and the lowest amount in the red seaweeds (C. elongate and J. rubens). Similar protein contents for these macroalgae classes were reported in other studies (Polat \& Ozogul, 2013; El-Shenody et al. 2019). Stirk et al. (2007) and Gressler et al. (2010) reported that the cause of these variations could be that the seaweeds protein content changes between species and within the same species because of levels of maturity, time of the year and different habitats.

Lipids supply much more power in oxidation processes than other biological components as they have abundant $-\mathrm{C}=\mathrm{O}$ - bonds For living organisms, they comprise a suitable storage material, mainly due to their large reduction levels. The differences in lipid contents were assigned to either environmental parameters or species types, or both of them (Chandini et al. 2008). Brown seaweeds usually had the highest total lipid content and then red seaweeds (Table 4) and this evaluation is in accordance with the findings of Gosch et al. (2012) and El-Shenody et al. (2019).

Total lipids were showed to be in general low. On the dry weight basis (\%), the lipid contents of the four species were between $0.33 \%$ and $5.92 \%$, depending on the algal species (Table 4). The highest lipid content was recorded in T. atomaria $(5.92 \% \pm 0.09)$, and the lowest in C. elongate $0.33 \% \pm 0.06$ ). Herbreteau et al. (1997) stated that total lipid contents were always below $4 \%$ in most species. This generalized evaluation is in agreement with the results of, Gosch et al. (2012). The relatively high total lipid content $(5.92 \% \pm 0.09)$ observed in T. atomaria are explained by Gosch et al. (2012) and El-Shenody et al. (2019) who found that some species are distinct, as the species of the order Dictyotales, which can record total lipid contents more than $20 \%$ of the dry weight. While the result showed for the red algae J. rubens $(1.42 \% \pm 0.0)$ was higher than the result reported by Polat \& Ozogul (2013), who mentioned the total lipid content (\%DW) for J. rubens in different seasons, which varied between $0.19 \%$ and $0.85 \%$. The result obtained for P. pavonia $(1.42 \% \pm 0.0)$ was consistent with the total lipid content detected in the $P$. pavonia earlier investigated, which ranged from $2.87 \%$ to $3.87 \%$ of the dry weight in different seasons (Polat \& Ozogul, 2013).

\subsection{Fatty acids profile of collected seaweeds}

Variations in fatty acid contents are due to both environmental and genetic diversity (Nelson et al., 2002). This diversity may be owing to their having been collected at different sites and/or to the drying effects (Chan et al., 1997). Considering the fatty acids composition, 25 components were showed with varying amounts between the four collected species (Table 5 and Figure 3 ). The percentage of saturated fatty acids (SAFA) of the collected seaweeds could be arranged in the following sequence 
J. rubens $>$ P. pavonia $>$ C. elongate $>$ T. atomaria. Red algae showed high percentages of SAFA than the brown algae, and these results agree with previous studies (Khairy \& El-Shafay, 2013; Polat \& Ozogul, 2013; Ismail, 2017; El-Shenody et al., 2019). Nine saturated fatty acids (SAFA) were detected in the tested seaweeds. Palmitic acid methyl ester (C17:0) was the major saturated fatty acids (SAFA) found in all species with different percentages, and the highest percentages were showed in J. rubens $(68.3 \%)$. Palmitic acid methyl ester (C17:0) was the largest constituent between the SAFAs in the present study, and this in agreement with most studies (Gressler et al., 2010; Fatma et al., 2015).

Eight monounsaturated fatty acids (MUSFA) were investigated in the four studied species; the highest percentage of MUSFA was $(50.09 \%)$ in C. elongate. The percentages of MUFA in red algae C. elongate were greater than P. pavonia and T. atomaria and this in agreement with those of (Khairy \& El-Shafay, 2013). Palmitoleic acid methyl ester ( $\omega 7)$ (C17:1) and Oleic acid methyl ester ( $\omega 9)$ (C19:1) were the most dominant monounsaturated fatty acids (MUSFA) and this in agreement with (Ismail et al.,
2016; El-Shenody et al., 2019). Oleic acid, an $\omega 9$ fatty acid, showed the largest percentage between the MUSFA in T. atomaria and P. pavonia, in accordance with the findings of El Baz et al. (2014) and Fatma et al. (2015) observed that oleic acid presented the greatest fraction of the MUSFA in T. atomaria and P. pavonia. It is important to the point that the fatty acid contents of the four seaweeds may showed their suitability for production of biofuel, since the four studied seaweeds record very large percentages of SAFAs when compared to the MUSFA and PUSFA (Gosch et al., 2012; Piligaev et al., 2019), with a relatively high content of MUSFA which would improve the biofuel quality (Knothe, 2008; Zhang et al., 2020).

Seven Polyunsaturated essential fatty acids (PUSFA) were appeared in (Table 5 and Figure 3), Eicosapentaenoic acid (EPA) acid (omega-3), which is the major dietary base for aquaculture, comprised the main sources of omega-3 and omega-6 long-chain PUFAs in seaweeds. The omega ( $\omega 3)$ fatty acids are stated as $\alpha$-Linolenic acid (ALA) methyl ester (C19:3), Stearidonic acid methyl ester (C19:4) and Eicosapentaenoic

Table 5. Fatty acids composition of the four studied seaweeds (\% of the total of fatty acid).

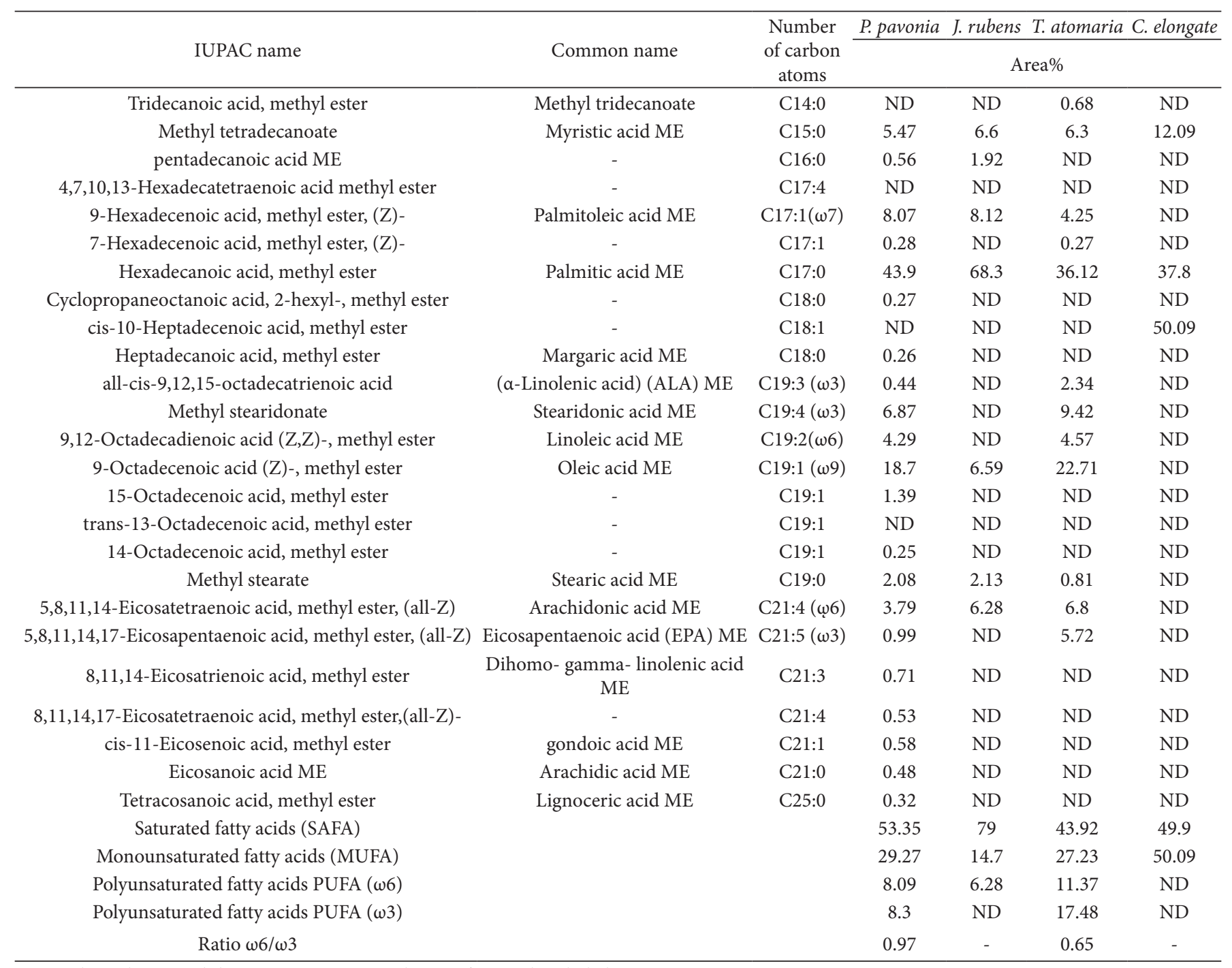

ND not detected, $\mathrm{ME}=$ methyl ester, IUPAC=International Union of Pure and Applied Chemistry. 

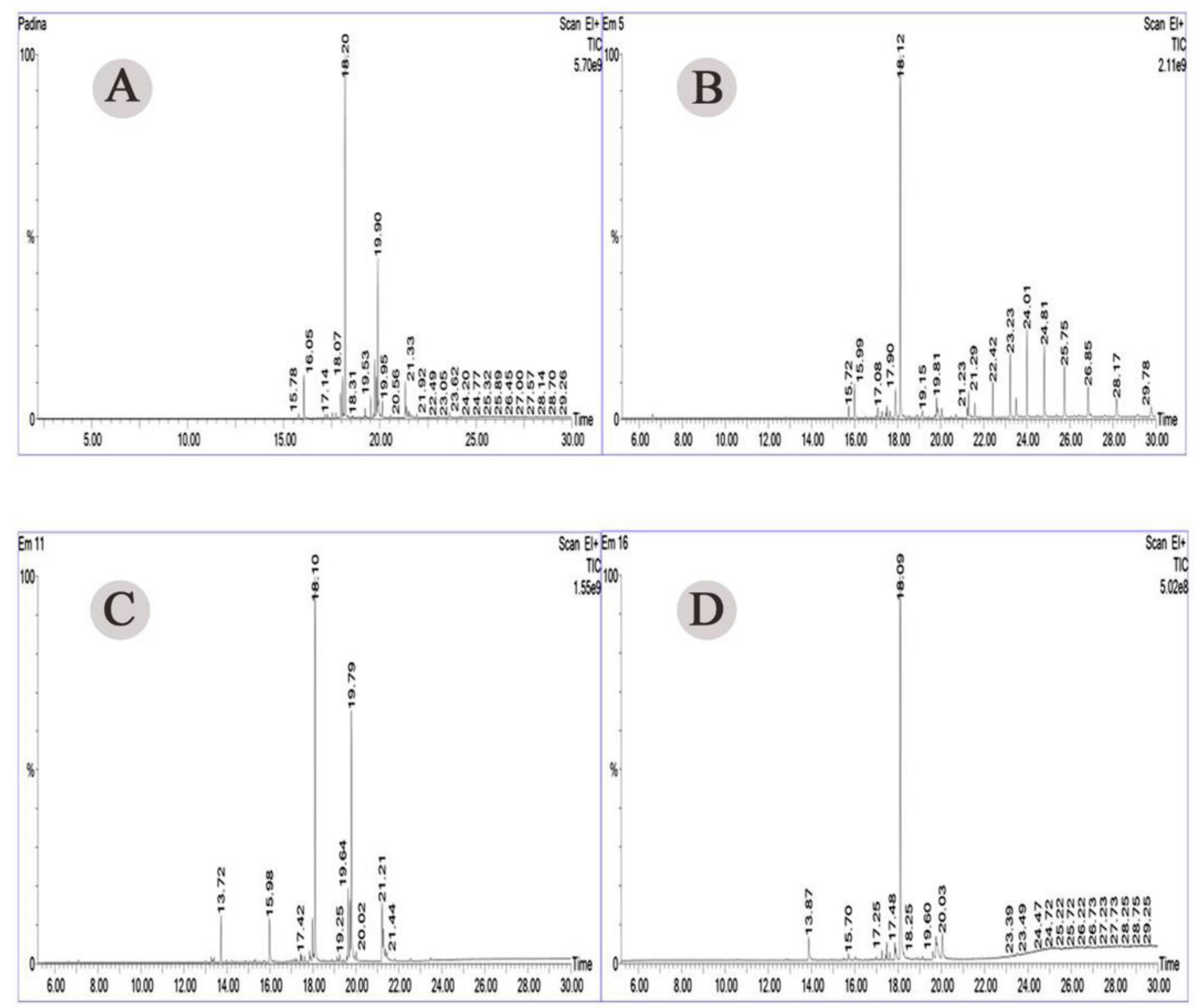

Figure 3. A chromatogram of the fatty acid methyl esters (FAMEs) of a dried seaweed sample. (A) P. pavonia, (B) J. rubens, (C) T. atomaria and (D) C. elongate.

acid methyl ester (EPA) (C21:5) in T. atomaria and P. pavonia only, while $T$. atomaria was recorded the highest percentages in the $\omega 3$ fatty acids $(2.34 \%, 9.42 \%$, and $5.72 \%$ respectively). Moreover, Linoleic acid methyl ester ( $\omega 6)$ (C19:2) was detected in T. atomaria and P. pavonia only with percentages $(4.57 \%$ and $4.29 \%)$, respectively. These data are in agreement with those of Fatma et al. (2015), who reported that important long-chain polyunsaturated fatty acids (PUFAs) were found at the highest level in T. atomaria and P. pavonia.

The $\omega 6$ and $\omega 3$ are the two groups of essential fatty acids. EFAs can't be synthesized within the body, so they must be supplied in the food. Furthermore, $\omega 6$ fatty acids also play an important role in normal growth and development, in addition to brain function. P. pavonia and T. atomaria included $\omega 6$ and $\omega 3$ fatty acids, which is one of the essential fatty acids. Linoleic acid $(\omega 6, \mathrm{C} 18: 2)$ and $\alpha$-linolenic acid ( $\omega 3, \mathrm{C18:3)}$ are PUFA, which cannot be synthesized by vertebrates, including humans and these fatty acids are present in this study with T. atomaria and $P$. pavonia and this in agreement with (Fatma et al., 2015). In the body, both can be changed into other PUFAs as eicosapentaenoic

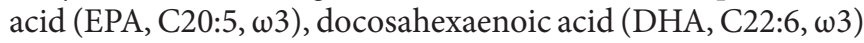
and arachidonic acid (C20:4, w6) (Van Ginneken et al., 2011). Depend on fatty acid compositions, seaweeds have a shortage of DHA, but they can produce arachidonic acid and eicosapentaenoic acid at very large levels (Sánchez-Machado et al., 2004). In the literature, DHA was not noticed in seaweeds or presents in very small amounts in various phaeophytes (Li et al., 2002).

Differential use of the studied seaweeds to decrease the risk of multiple sclerosis, inflammation, diabetes mellitus, cancer, and coronary heart disease may be based on the variations in the contents of $\omega 3$ fatty acids. Simopoulos (2002) mentioned that the $\omega 3$ fatty acids have beneficial health effects, which included benefits concerning inflammatory bowel disease, cancer, psoriasis, and rheumatoid arthritis. In scientific reports, the 
significance of the $\omega 6 / \omega 3$ ratio has been widely argued recently. The equilibrium of assimilation of both PUSFA $\omega 6$ and $\omega 3$ fatty acids achieved when the $\omega 6 / \omega 3$ ratio was equal to 1 (Francavilla et al., 2013).The total percentage of fatty acids of $\omega 6$ and $\omega 3$ of the collected seaweeds could be arranged in the following sequence P. pavonia $>$ T. atomaria (Table 5 and Figure 3). However, the ratio of $\omega 6 / \omega 3$ of T. atomaria (0.65\%) and P. pavonia (0.97\%) is the lowest among the studied seaweeds. This demonstrates that T. atomaria and P. pavonia are more desirable in decreasing the risk of many chronic diseases. The $\omega 6$ and $\omega 3$ fatty acids of $P$. pavonia in the current study were higher than the values previously reported, including for Padina tetrastromatica (2.2\% and $1.02 \%$, respectively) (Ismail et al., 2016). In addition, the ratio of $\omega 6 / \omega 3$ was 0.65 and 0.97 for the T. atomaria and P. pavonia, respectively. According to WHO this ratio should not be greater than 10 in diets (Sánchez-Machado et al. 2004), which recommend the studied seaweeds for nutritive purposes after further investigations.

\section{Conclusion}

The seaweeds T. atomaria, P. pavonia, J. rubens, and C. elongate collected from Rocky Bay of Abu Qir in Alexandria, Egypt, are rich with high levels of proteins, carbohydrates, lipids, and fatty acids; therefore they consider as foods with low calories. Furthermore, they may have a promising role in industrial applications, feed, and food. These seaweeds extracted using the traditional extraction methods and exhibited high antioxidant activities with massive biomedical, pharmaceutical, and nutraceutical applications. The in vitro antioxidant activities of different solvents of these seaweeds showed dose dependency. In general, methanol and ethanol extracts of the seaweeds were more efficient than diethyl ether, hexane, aqueous cold, and hot aqueous extracts. T. atomaria was the most nutritionally promising species, with intermediate carbohydrate content, suitable protein contents, and high lipid content with a great amount of polyunsaturated fatty acids (especially omega-3and omega-6), with a suitable $\omega 6 / \omega 3$ ratio and high antioxidant activity. T. atomaria is a good candidate for oil-based products due to their total lipid content $>5 \% \mathrm{DW}$. These natural economic resources should be utilized and improved; therefore, many future studies must be carried out.

\section{Acknowledgments}

We would like to thank Dr. Mona M. Ismail (Assistant Professor of Phycology National Institute of Oceanography and Fisheries, Alexandria, Egypt) for her help in identifying the algae used in this research paper

\section{References}

Abifarin, T. O., Afolayan, A. J., \& Otunola, G. A. (2019). Phytochemical and antioxidant activities of Cucumis africanus Lf: a wild vegetable of South Africa. Journal of Evidence-based Integrative Medicine, 24, 24. http://dx.doi.org/10.1177/2515690X19836391. PMid:30917681.

Adwas, A., Elsayed, A., \& Azab, A. (2019). Oxidative stress and antioxidant mechanisms in human body. Journal of Applied Biotechnology \& Bioengineering, 6(1), 43-47.
Agregán, R., Lorenzo, J. M., Munekata, P. E. S., Dominguez, R., Carballo, J., \& Franco, D. (2017). Assessment of the antioxidant activity of Bifurcaria bifurcata aqueous extract on canola oil. Effect of extract concentration on the oxidation stability and volatile compound generation during oil storage. Food Research International, 99(Pt 3), 1095-1102. http://dx.doi.org/10.1016/j.foodres.2016.10.029. PMid:28865620.

Agregán, R., Munekata, P. E. S., Franco, D., Carballo, J., Barba, F. J., \& Lorenzo, J. M. (2018). Antioxidant potential of extracts obtained from macro-(Ascophyllum nodosum, Fucus vesiculosus and Bifurcaria bifurcata) and micro-algae (Chlorella vulgaris and Spirulina platensis) assisted by ultrasound. Medicines (Basel, Switzerland), 5(2), 33. http:// dx.doi.org/10.3390/medicines5020033. PMid:29642562.

Al-Araby, S. Q., Rahman, M. A., Chowdhury, M. A. H., Das, R. R., Chowdhury, T. A., Hasan, C. M. M., Afroze, M., Hashem, M. A., Hajjar, D., Alelwani, W., Makki, A. A., \& Haque, M. A. (2020). Padina tenuis (marine alga) attenuates oxidative stress and streptozotocin-induced type 2 diabetic indices in Wistar albino rats. South African Journal of Botany, 128, 87-100. http://dx.doi.org/10.1016/j.sajb.2019.09.007.

Al-Dabbas, M. M. (2017). Antioxidant activity of different extracts from the aerial part of Moringa peregrina (Forssk.) Fiori, from Jordan. Pakistan Journal of Pharmaceutical Sciences, 30(6), 21512157. PMid:29175784.

Aleem, A. A. (1993). The marine Algae of Alexandria, Egypt (pp. 1-55). Alexandria: Privately Published.

Apak, R., Özyürek, M., Güçlü, K., \& Çapanoğlu, E. (2016). Antioxidant activity/capacity measurement. 2. Hydrogen atom transfer (HAT)-based, mixed-mode (electron transfer (ET)/HAT), and lipid peroxidation assays. Journal of Agricultural and Food Chemistry, 64(5), 10281045. http://dx.doi.org/10.1021/acs.jafc.5b04743. PMid:26805392.

Barba, F. J. (2017). Microalgae and seaweeds for food applications: challenges and perspectives. Food Research International (Ottawa, Ont.), 99(Pt 3), 969-970. http://dx.doi.org/10.1016/j.foodres.2016.12.022. PMid:28865622.

Barbosa, A. I., Coutinho, A. J., Costa Lima, S. A., \& Reis, S. (2019). Marine Polysaccharides in Pharmaceutical Applications: Fucoidan and Chitosan as Key Players in the Drug Delivery Match Field. Marine Drugs, 17(12), 654. http://dx.doi.org/10.3390/md17120654. PMid:31766498.

Bradford, M. M. (1976). A rapid and sensitive method for the quantitation of microgram quantities of protein utilizing the principle of proteindye binding. Analytical Biochemistry, 72(1-2), 248-254. http://dx.doi. org/10.1016/0003-2697(76)90527-3. PMid:942051.

Cardozo, K. H., Guaratini, T., Barros, M. P., Falcão, V. R., Tonon, A. P., Lopes, N. P., Campos, S., Torres, M. A., Souza, A. O., Colepicolo, P., \& Pinto, E. (2006). Metabolites from algae with economical impact. Comparative Biochemistry and Physiology. Toxicology \& Pharmacology: CBP PMid:16901759.

Chakraborty, K., Joseph, D., \& Praveen, N. K. (2015). Antioxidant activities and phenolic contents of three red seaweeds (Division: Rhodophyta) harvested from the Gulf of Mannar of Peninsular India. Journal of Food Science and Technology, 52(4), 1924-1935. http://dx.doi.org/10.1007/s13197-013-1189-2. PMid:25829573.

Chan, J. C.-C., Cheung, P. C.-K., \& Ang, P. O. (1997). Comparative studies on the effect of three drying methods on the nutritional composition of seaweed Sargassum hemiphyllum (Turn.) C. Ag. Journal of Agricultural and Food Chemistry, 45(8), 3056-3059. http:// dx.doi.org/10.1021/jf9701749.

Chandini, K. S., Ganesan, P., Suresh, P. V., \& Bhaskar, N. (2008). Seaweeds as a source of nutritionally beneficial compounds-a review. Journal of Food Science and Technology, 45(1), 1. 
Duh, P.-D. (1998). Antioxidant activity of burdock (Arctium lappa Linné): Its scavenging effect on free-radical and active oxygen. Journal of the American Oil Chemists' Society, 75(4), 455-461. http:// dx.doi.org/10.1007/s11746-998-0248-8.

El Baz, F. K., El-Baroty, G. S., Ibrahim, A. E., \& Abd El Baky, H. H. (2014). Cytotoxicity, antioxidants and antimicrobial activities of lipids extracted from some Marine Algae. Journal of Aquaculture Research \& Development, 5(284), 2.

El-Shenody, R. A., Ashour, M., \& Ghobara, M. M. E. (2019). Evaluating the chemical composition and antioxidant activity of three Egyptian seaweeds: Dictyota dichotoma, Turbinaria decurrens, and Laurencia obtusa. Brazilian Journal of Food Technology, 22, 22. http://dx.doi. org/10.1590/1981-6723.20318.

Fatma, C. A. F., Yilmaz, Ö., Durucan, F., \& Özdemir, N. Ş. (2015). Biochemical components of three marine macroalgae (Padina pavonica, Ulva lactuca and Taonia atomaria) from the levantine sea coast of antalya, Turkey. Journal of Biological and Environmental Sciences, 6, 401-411.

Fleurence, J., Morançais, M., Dumay, J., Decottignies, P., Turpin, V., Munier, M., Garcia-Bueno, N., \& Jaouen, P. (2012). What are the prospects for using seaweed in human nutrition and for marine animals raised through aquaculture? Trends in Food Science \& Technology, 27(1), 57-61. http://dx.doi.org/10.1016/j.tifs.2012.03.004.

Folch, J., Lees, M., \& Sloane Stanley, G. H. (1957). A simple method for the isolation and purification of total lipides from animal tissues. The Journal of Biological Chemistry, 226(1), 497-509. PMid:13428781.

Francavilla, M., Franchi, M., Monteleone, M., \& Caroppo, C. (2013). The red seaweed Gracilaria gracilis as a multi products source. Marine Drugs, 11(10), 3754-3776. http://dx.doi.org/10.3390/md11103754. PMid:24084791.

Ganesan, P., Kumar, C. S., \& Bhaskar, N. (2008). Antioxidant properties of methanol extract and its solvent fractions obtained from selected Indian red seaweeds. Bioresource Technology, 99(8), 2717-2723. http://dx.doi.org/10.1016/j.biortech.2007.07.005. PMid:17706415.

Gosch, B. J., Magnusson, M., Paul, N. A., \& de Nys, R. (2012). Total lipid and fatty acid composition of seaweeds for the selection of species for oil-based biofuel and bioproducts. Global Change Biology. Bioenergy, 4(6), 919-930. http://dx.doi.org/10.1111/j.1757-1707.2012.01175.x.

Gressler, V., Yokoya, N. S., Fujii, M. T., Colepicolo, P., Mancini, J. Fo., Torres, R. P., \& Pinto, E. (2010). Lipid, fatty acid, protein, amino acid and ash contents in four Brazilian red algae species. Food Chemistry, 120(2), 585-590. http://dx.doi.org/10.1016/j.foodchem.2009.10.028.

Guiry, M. D., \& Guiry, G. M. (2019). AlgaeBase. World-wide electronic publication. Galway: National University of Ireland. Retrieved from Http://Www.Algaebase.Org

Herbreteau, F., Coiffard, L. J. M., Derrien, A., \& De Roeck-Holtzhauer, Y. (1997). The fatty acid composition of five species of macroalgae. Botanica Marina, 40(1-6), 25-28. http://dx.doi.org/10.1515/ botm.1997.40.1-6.25.

Hossain, Z., Kurihara, H., \& Takahashi, K. (2003). Biochemical composition and lipid compositional properties of the brown alga Sargassum horneri. Pakistan Journal of Biological Sciences, 6(17), 1497-1500. http://dx.doi.org/10.3923/pjbs.2003.1497.1500.

Ibrahim, E. A., Aly, H. F., Baker, D. H. A., Mahmoud, K., \& El-Baz, F. K. (2016). Marine algal sterol hydrocarbon with anti-inflammatory, anticancer and anti-oxidant properties. International Journal of Pharma and Bio Sciences, 7, 392-398.

Indu, H., \& Seenivasan, R. (2013). In vitro antioxidant activity of selected seaweeds from southeast coast of India. International Journal of Pharmacy and Pharmaceutical Sciences, 5(2), 474-484.
Ismail, G. A. (2017). Biochemical composition of some Egyptian seaweeds with potent nutritive and antioxidant properties. Food Science and Technology (Campinas), 37(2), 294-302. http://dx.doi. org/10.1590/1678-457x.20316.

Ismail, G. A., Gheda, S. F., Abo-Shady, A. M., \& Abdel-Karim, O. H. (2019). In vitro potential activity of some seaweeds as antioxidants and inhibitors of diabetic enzymes. Food Science and Technology, In press. https://doi.org/10.1590/fst.15619.

Ismail, M. M., El Zokm, G. M., \& El-Sayed, A. A. M. (2017). Variation in biochemical constituents and master elements in common seaweeds from Alexandria Coast, Egypt, with special reference to their antioxidant activity and potential food uses: prospective equations. Environmental Monitoring and Assessment, 189(12), 648. http://dx.doi.org/10.1007/s10661-017-6366-8. PMid:29177576.

Ismail, M. M., Gheda, S. F., \& Pereira, L. (2016). Variation in bioactive compounds in some seaweeds from Abo Qir bay, Alexandria, Egypt. Rendiconti Lincei, 27(2), 269-279. http://dx.doi.org/10.1007/ s12210-015-0472-8.

J Mbah, C., Orabueze, I., \& H Okorie, N. (2019). Antioxidants properties of natural and synthetic chemical compounds: therapeutic effects on biological system. Acta Scientific Pharmaceutical Sciences, 3(6), 28-42. http://dx.doi.org/10.31080/ASPS.2019.03.0273.

Jha, B., Reddy, C. R. K., Thakur, M. C., \& Rao, M. U. (2009). Seaweeds of India: the diversity and distribution of seaweeds of gujarat coast (Vol. 3). USA: Springer Science \& Business Media. http://dx.doi. org/10.1007/978-90-481-2488-6.

John, R. P., \& Anisha, G. S. (2012). Macroalgae and their potential for biofuel. Plant Sciences Reviews, 2011, 151-162.

Kanaan H., \& Belous, O. (2016). Marine algae of the Lebanese coast. New York: Nova Science Publisher, Inc.

Kelman, D., Posner, E. K., McDermid, K. J., Tabandera, N. K., Wright, P. R., \& Wright, A. D. (2012). Antioxidant activity of Hawaiian marine algae. Marine Drugs, 10(2), 403-416. http://dx.doi.org/10.3390/ md10020403. PMid:22412808.

Khairy, H. M., \& El-Shafay, S. M. (2013). Seasonal variations in the biochemical composition of some common seaweed species from the coast of Abu Qir Bay, Alexandria, Egypt. Oceanologia, 55(2), 435-452. http://dx.doi.org/10.5697/oc.55-2.435.

Knothe, G. (2008). "Designer" biodiesel: optimizing fatty ester composition to improve fuel properties. Energy \& Fuels, 22(2), 1358-1364. http:// dx.doi.org/10.1021/ef700639e.

Kochert, G. (1973). Colony differentiation in green algae. In S. J. Coward (Ed.), Developmental regulation: aspects of cell differentiation (pp. 155-167). New York: Academic Press. http://dx.doi.org/10.1016/ B978-0-12-194050-8.50011-1.

Kokabi, M., Yousefzadi, M., Feghhi, M. A., \& Keshavarz, M. (2013). Antioxidant activity of extracts of selected algae from the Persian Gulf, Iran. Journal of the Persian Gulf, 4(12), 45-50.

Kumaran, A., \& Karunakaran, R. J. (2007). In vitro antioxidant activities of methanol extracts of five Phyllanthus species from India. Lebensmittel-Wissenschaft + Technologie, 40(2), 344-352. http://dx.doi.org/10.1016/j.lwt.2005.09.011.

Larson, R. A. (1995). Plant defenses against oxidative stress. Archives of Insect Biochemistry and Physiology, 29(2), 175-186. http://dx.doi. org/10.1002/arch.940290207. PMid:28833491.

Li, X., Fan, X., Han, L., \& Lou, Q. (2002). Fatty acids of some algae from the Bohai Sea. Phytochemistry, 59(2), 157-161. http://dx.doi. org/10.1016/S0031-9422(01)00437-X. PMid:11809450.

Li, Y., Guo, C., Yang, J., Wei, J., Xu, J., \& Cheng, S. (2006). Evaluation of antioxidant properties of pomegranate peel extract in comparison 
with pomegranate pulp extract. Food Chemistry, 96(2), 254-260. http://dx.doi.org/10.1016/j.foodchem.2005.02.033.

Lie Ken Jie, M. S. (1989). Fatty acids and glycerides. Natural Product Reports, 6(3), 231-261.

Lopez-Santamarina, A., Miranda, J. M., Mondragon, A. del C., Lamas, A., Cardelle-Cobas, A., Franco, C. M., \& Cepeda, A. (2020). Potential use of marine seaweeds as prebiotics: A review. Molecules (Basel, Switzerland), 25(4), 1004. http://dx.doi.org/10.3390/molecules25041004. PMid:32102343.

Maisuthisakul, P., \& Pongsawatmanit, R. (2004). Effect of sample preparation methods and extraction time on yield and antioxidant activity from kradonbok (Careya sphaerica Roxb.) leaves. Witthayasan Kasetsat Witthayasat, 38(5), 8-14.

Manch, N., Melpha, Y., \& James, J. E. (2014). Phytochemical investigation of the three species of Ulva from Rasthacaud coast, Tamil Nadu, India. Journal of Chemical and Pharmaceutical Research, 6(8), 321-329.

McDermid, K. J., \& Stuercke, B. (2003). Nutritional composition of edible Hawaiian seaweeds. Journal of Applied Phycology, 15(6), 513-524. http://dx.doi.org/10.1023/B:JAPH.0000004345.31686.7f.

Mohy El-Din, S. M., \& El-Ahwany, A. M. D. (2016). Bioactivity and phytochemical constituents of marine red seaweeds (Jania rubens, Corallina mediterranea and Pterocladia capillacea). Journal of Taibah University for Science, 10(4), 471-484. http://dx.doi.org/10.1016/j. jtusci.2015.06.004.

Nahas, R., Abatis, D., Anagnostopoulou, M. A., Kefalas, P., Vagias, C., \& Roussis, V. (2007). Radical-scavenging activity of Aegean Sea marine algae. Food Chemistry, 102(3), 577-581. http://dx.doi. org/10.1016/j.foodchem.2006.05.036.

Nelson, M., Phleger, C., \& Nichols, P. (2002). Seasonal lipid composition of the red alga Palmaria palmate. Botanica Marina, 36(2), 169-174.

O’Sullivan, L., Murphy, B., McLoughlin, P., Duggan, P., Lawlor, P. G., Hughes, H., \& Gardiner, G. E. (2010). Prebiotics from marine macroalgae for human and animal health applications. Marine Drugs, 8(7), 2038-2064. http://dx.doi.org/10.3390/md8072038. PMid:20714423.

Offei, F., Mensah, M., Kemausuor, F., \& Thygesen, A. (2019). A biorefinery approach to bioethanol and bioelectricity co-production from tropical seaweeds. Journal of Applied Phycology, 31(6), 3899-3913. http://dx.doi.org/10.1007/s10811-019-01887-6.

Pádua, M., Fontoura, P. S. G., \& Mathias, A. L. (2004). Chemical composition of Ulvaria oxysperma (Kützing) bliding, Ulva lactuca (Linnaeus) and Ulva fascita (Delile). Brazilian Archives of Biology and Technology, 47(1), 49-55. http://dx.doi.org/10.1590/S151689132004000100007.

Payne, J. K., \& Stewart, J. R. (1988). The chemical composition of the thallus wall of Characiosiphon rivularis (Characiosiphonaceae, Chlorophyta). Phycologia, 27(1), 43-49. http://dx.doi.org/10.2216/ i0031-8884-27-1-43.1.

Peng, L., Lan, F., \& Lan, C. Q. (2020). Biofuels from microalgae and seaweeds: potentials of industrial scale production. In A. A. Vertès, N. Qureshi, H. P. Blaschek \& H. Yukawa (Ed.), Green energy to sustainability: strategies for global industries. Hoboken: John Wiley \& Sons, Inc. http://dx.doi.org/10.1002/9781119152057.ch9.

Pérez-Jiménez, J., \& Saura-Calixto, F. (2006). Effect of solvent and certain food constituents on different antioxidant capacity assays. Food Research International, 39(7), 791-800. http://dx.doi.org/10.1016/j. foodres.2006.02.003.

Piligaev, A. V., Sorokina, K. N., Samoylova, Y. V., \& Parmon, V. N. (2019). Production of microalgal biomass with high lipid content and their catalytic processing into biodiesel: a review. Catalysis in Industry, 11(4), 349-359. http://dx.doi.org/10.1134/S207005041904007X.

Pirian, K., Moein, S., Sohrabipour, J., Rabiei, R., \& Blomster, J. (2017). Antidiabetic and antioxidant activities of brown and red macroalgae from the Persian Gulf. Journal of Applied Phycology, 29(6), 31513159. http://dx.doi.org/10.1007/s10811-017-1152-0.

Polat, S., \& Ozogul, Y. (2013). Seasonal proximate and fatty acid variations of some seaweeds from the northeastern Mediterranean coast. Oceanologia, 55(2), 375-391. http://dx.doi.org/10.5697/oc.55-2.375.

Porzio, L., Buia, M. C., Lorenti, M., Vitale, E., Amitrano, C., \& Arena, C. (2018). Ecophysiological response of Jania rubens (Corallinaceae) to ocean acidification. Rendiconti Lincei. Scienze Fisiche e Naturali, 29(3), 543-546. http://dx.doi.org/10.1007/s12210-018-0719-2.

Radwan, S. S. (1978). Coupling of two-dimensional thin-layer chromatography with gas chromatography for the quantitative analysis of lipid classes and their constituent fatty acids. Journal of Chromatographic Science, 16(11), 538-542. http://dx.doi.org/10.1093/ chromsci/16.11.538.

Rady, A. A., El-Sheekh, M. M., \& Matkovics, B. (1994). Temperature shiftinduced changes in the antioxidant enzyme system of Cyanobacterium Synechocystis PCC 6803. The International Journal of Biochemistry, 26(3), 433-435. http://dx.doi.org/10.1016/0020-711X(94)90064-7.

Robledo, D., \& Freile Pelegrín, Y. (1997). Chemical and mineral composition of six potentially edible seaweed species of Yucatan. Botanica Marina, 40(1-6), 301-306. http://dx.doi.org/10.1515/ botm.1997.40.1-6.301.

Saeed, A., Abotaleb, S., Alam, N., ELMehalawy, A., \& Gheda, S. (2020). In vitro assessment of antimicrobial, antioxidant and anticancer activities of some marine macroalgae. Egyptian Journal of Botany, 60(1), 81-96. http://dx.doi.org/10.21608/EJBO.2019.11363.1303.

Safer, A. M., \& Al-Nughamish, A. J. (1999). Hepatotoxicity induced by the anti-oxidant food additive, butylated hydroxytoluene BHT, in rats. An electron microscopical study. Histology and Histopathology, 14(2), 391-406. PMid:10212800.

Sala, E., \& Boudouresque, C. F. (1997). The role of fishes in the organization of a Mediterranean sublittoral community.: I: Algal communities. Journal of Experimental Marine Biology and Ecology, 212(1), 25-44. http://dx.doi.org/10.1016/S0022-0981(96)02745-1.

Sánchez-Machado, D. I., López-Cervantes, J., Lopez-Hernandez, J., \& Paseiro-Losada, P. (2004). Fatty acids, total lipid, protein and ash contents of processed edible seaweeds. Food Chemistry, 85(3), 439444. http://dx.doi.org/10.1016/j.foodchem.2003.08.001.

Santos-Sánchez, N. F., Salas-Coronado, R., Villanueva-Cañongo, C., \& Hernández-Carlos, B. (2019). Antioxidant compounds and their antioxidant mechanism. In E. Shalaby. Antioxidants. London: IntechOpen. http://dx.doi.org/10.5772/intechopen.85270.

Shannon, E., \& Abu-Ghannam, N. (2019). Seaweeds as nutraceuticals for health and nutrition. Phycologia, 58(5), 563-577. http://dx.doi. org/10.1080/00318884.2019.1640533.

Simopoulos, A. P. (2002). Omega-3 fatty acids in inflammation and autoimmune diseases. Journal of the American College of Nutrition, 21(6), 495-505. http://dx.doi.org/10.1080/07315724.2002.1071924 8. PMid:12480795.

Stirk, W. A., Reinecke, D. L., \& van Staden, J. (2007). Seasonal variation in antifungal, antibacterial and acetylcholinesterase activity in seven South African seaweeds. Journal of Applied Phycology, 19(3), 271276. http://dx.doi.org/10.1007/s10811-006-9134-7.

Sudhakar, K., Mamat, R., Samykano, M., Azmi, W. H., Ishak, W. F. W., \& Yusaf, T. (2018). An overview of marine macroalgae as bioresource. 
Renewable \& Sustainable Energy Reviews, 91, 165-179. http://dx.doi. org/10.1016/j.rser.2018.03.100.

Sumayya, S. S., \& Murugan, K. (2019). Antioxidant potentialities of marine red algae Gracillaria dura: a search. The Pharma Innovation Journal, 8(4), 1157-1161.

Sun, N. L., Zhang, J., Lu, X., Zhang, L., \& Zhang, Y. (2011). Evaluation to the antioxidant activity of total flavonoids extract from persimmon (Diospyros kaki L.) leaves. Food and Chemical Toxicology, 49(10), 2689-2696. http://dx.doi.org/10.1016/j.fct.2011.07.042. PMid:21802475.

Truong, D.-H., Nguyen, D. H., Ta, N. T. A., Bui, A. V., Do, T. H., \& Nguyen, H. C. (2019). Evaluation of the use of different solvents for phytochemical constituents, antioxidants, and in vitro antiinflammatory activities of Severinia buxifolia. Journal of Food Quality, 2019, 2019. http://dx.doi.org/10.1155/2019/8178294.

Turkmen, N., Sari, F., \& Velioglu, Y. S. (2006). Effects of extraction solvents on concentration and antioxidant activity of black and black mate tea polyphenols determined by ferrous tartrate and Folin-Ciocalteu methods. Food Chemistry, 99(4), 835-841. http:// dx.doi.org/10.1016/j.foodchem.2005.08.034.

Van Ginneken, V. J. T., Helsper, J. P. F. G., de-Visser, W., van-Keulen, H., \& Brandenburg, W. A. (2011). Polyunsaturated fatty acids in various macroalgal species from north Atlantic and tropical seas. Lipids in Health and Disease, 10, 1-8. 10.1186/1476-511X-10-104

van Ngo, T., Scarlett, C. J., Bowyer, M. C., Ngo, P. D., \& Van Vuong, Q. (2017). Impact of different extraction solvents on bioactive compounds and antioxidant capacity from the root of Salacia chinensis L. Journal of Food Quality, •••, 2017.
Venkatesan, J., Anil, S., \& Kim, S.-K. (2017). Seaweed Polysaccharides: isolation, biological and biomedical applications. USA: Elsevier.

Wijesekara, I., Senevirathne, M., Li, Y.-X., \& Kim, S.-K. (2012). Functional ingredients from marine algae as potential antioxidants in the food industry. In S.-K. Kim (Ed.), Handbook of marine macroalgae (pp. 398-402). Hoboken: John Wiley \& Sons, Inc.

Yi, Z., Yin-shan, C., \& Hai-sheng, L. (2001). Screening for antibacterial and antifungal activities in some marine algae from the fujian coast of China with three different solvents. Chinese Journal of Oceanology and Limnology, 19, 327-331.

Yoshii, Y., Hanyuda, T., Wakana, I., Miyaji, K., Arai, S., Ueda, K., \& Inouye, I. (2004). Carotenoid compositions of Cladophora balls (Aegagropila linnaei) and some members of the cladophorales (Ulvophyceae, Chlorophyta): their taxonomic and evolutionary implication 1. Journal of Phycology, 40(6), 1170-1177. http://dx.doi. org/10.1111/j.1529-8817.2004.03210.x.

Yuan, Y. V., Bone, D. E., \& Carrington, M. F. (2005). Antioxidant activity of dulse (Palmaria palmata) extract evaluated in vitro. Food Chemistry, 91(3), 485-494. http://dx.doi.org/10.1016/j.foodchem.2004.04.039.

Zhang, Y.-Q., Jin, L., Duan, J., Zhao, G.-C., Xu, Y.-Y., Liu, J.-M., Jia, L.M., Hao, Y.-B., \& Su, S.-C. (2020). The Assessment of two species of soapberry as resources for high-quality biodiesel production with an optimized method of ultrasound-assisted oil extraction. Forests, 11(2), 212. http://dx.doi.org/10.3390/f11020212.

Zubia, M., Robledo, D., \& Freile-Pelegrin, Y. (2007). Antioxidant activities in tropical marine macroalgae from the Yucatan Peninsula, Mexico. Journal of Applied Phycology, 19(5), 449-458. http://dx.doi. org/10.1007/s10811-006-9152-5. 